\title{
75. Paratranslation under constraint
}

\section{Ayşe Işık AKDAĞ'}

APA: Akdağ, A. I. (2021). Paratranslation under constraint. RumeliDE Dil ve Edebiyat Araştırmaları Dergisi, (24), 1260-1271. DOI: 10.29000/rumelide.995511.

\begin{abstract}
The aim of this article is to reveal how the paratext features of Georges Perec's La Disparition, which is one of the most striking examples of writing under constraint, affect the reception of the main text. The corpus consists of the Turkish copy Kayboluş translated by Cemal Yardimci and printed from Sel Publications in 2000 as well as the English version A-void translated by Gilbert Adair, published by Vintage Random House in 2008. The analysis will be based on Genette's paratext classification. Along with the elements that make up the peritext, the main text sections that are its extension (inserted chapters- translation diaries) will also be included. In particular, the design, colour and location of the title; The cover page, the table of contents and the translator's so-called interventions will be scrutinized. In addition, translation techniques such as addition and omission and how these techniques are reflected in the text and peritextual elements will also be discussed together with the translator's decisions. In conclusion, the research showed that the peritextual elements of both translations have shaped the reading process in different ways by making implicit or explicit allusions, acquired different functions in their respective cultures, attributed different roles to the reader, strengthened or weakened the visibility of the constraint as well as the visibility of the translator and affected the recreation degree of the main text.
\end{abstract}

Keywords: La Disparition, A-void, Kayboluş, paratext, translation

\section{Sınırlama altında yan metin çevirisi}

$\ddot{\mathbf{O} z}$

$\mathrm{Bu}$ makalenin amacı sınırlama altında yazının en dikkat çekici örneklerden biri olarak yazın dünyasında yer edinen Georges Perec'in La Disparition adlı eserindeki yan metin özelliklerinin ana metnin alımlanmasını nasıl etkilediğini ortaya koymaktır. İncelemenin bütüncesini Türkçe çeviri kitap Kayboluş ve İngilizce çeviri kitap A-void oluşturmaktadır. Cemal Yardımcı tarafından çevrilmiş Türkçe kitap 2006 yılında Sel Yayınlarından basılmış kopyadır. Gilbert Adair tarafından çevrilmiş İngilizce kitap 2008 yılında Vintage Random House Yayınevinden çıkmıştır. İnceleme Genette'in yan metin sınıflandırmasına dayalı olarak yapılacaktır. İncelemede özellikle çevre metni oluşturan unsurlarla birlikte çevre metnin ana metindeki uzantısı olan bölümler de (eklenen bölümlerçevirmen günceleri) yer alacaktır. Özellikle başlığın tasarımı, rengi ve konumu; kapak sayfası, içindekiler tablosu ve çevirmenin sözde metne müdahaleleri mercek altına alınacak başlıklardır. Ayrıca çevirmen kararları ile birlikte özellikle ekleme ve çıkarma gibi çeviri teknikleri ve bu tekniklerin metne ve çevre metinsel unsurlara nasıl yansıdı̆̆ı da ele alınacaktır. Sonuç olarak araştırma, her iki kitabın çevre metinsel öğelerinin örtük ya da açık göndermeler aracılığıyla okuma sürecini farklı yönlerde şekillendirdiğini ve kendi kültürlerinde farklı işlevler kazandığını

Öğr. Gör. Dr., İstanbul Üniversitesi, Yabancı Diller Yüksekokulu (İstanbul, Türkiye), aysea@istanbul.edu.tr,, ORCID ID: oooo-0003-4338-9071 [Araştırma makalesi, Makale kayıt tarihi: 09.07.2021-kabul tarihi: 20.09.2021; DOI: 10.29000/rumelide.995511]

RumeliDE Dil ve Edebiyat Araştırmaları Dergisi Osmanağa Mahallesi, Mürver Çiçeği Sokak, No:14/8 Kadıköy - ISTANBUL / TÜRKIYE 34714 e-posta: editor@rumelide.com tel: +90 $5057958124,+902167730616$
Address

RumeliDE Journal of Language and Literature Studies Osmanağa Mahallesi, Mürver Çiçeği Sokak, No:14/8

Kadıköy - ISTANBUL / TURKEY 34714

e-mail: editor@rumelide.com,

phone: +90 505 7958124, +90 2167730616 
göstermektedir. Ayrıca çevre metin öğelerin düzenlenişi okura farklı roller yüklemiştir. Yine bu etmenler kısıtlamanın görünürlügünün yanı sıra çevirmenin görünürlüğünü de güçlendirmiş ya da zayıflatmış ve ana metnin yeniden üretim derecesini etkilemiştir.

Anahtar kelimeler: La Disparition, A-void, Kayboluş, yan metin, çeviri

\section{Introduction}

In Paratexts: Threshold of Interpretation, Genette (1997, p. 5) defines paratexts as: "liminal devices and conventions, both within and outside the book, that form part of the complex mediation between book, author, publisher, and reader". He classifies paratexts based on their location. The first noticeable elements such as title, preface, chapter titles, title page, and appendages (non-exhaustive list) are called peritext and other elements that are not stated in the book such as interviews or critiques are called epitexts. Where translation is concerned, people think of the translation of the main text. Translation of paratextual elements is either considered in the second place or more often formed by the choice of publishing house. However, translation of paratexts may seriously affect the reception and the meaning of the main text (Alvstad, 2012; Armstrong, 2007; Sapiro, 2008; Watts, 2007). More precisely, the paratranslation (translation of paratexts) of Oulipian works requires much more attention, since they are formed according to a specific language and/or thematic rules which call into question the boundaries of paratexts with the main text. Although it is possible to find studies that tackle the relationship between paratexts and translation, the number of those that deal with the translation of Oulipian constraint-based works are few and paratranslation of Oulipian texts needs to be studied from the perspective of Translation Studies. As for the translation of La Disparition (Perec, 1969/2006) into other languages, the peritextual elements are not analysed systematically. Even though in some studies lipogrammatic features of English, Spanish or German translations are mentioned, other paratextual elements are not handled.

This study aims to demonstrate how the translation of peritexts affects the reader by examining the Turkish and English translations of La Disparition. The reason why this novel was chosen is that it features Oulipian constraints that integrate the paratext of the book with the plot of the story both in terms of theme and language games used. Thus, the research seeks answers to the following questions: To what extent do the two translations carry the theme of the book and language specific games to the peritext? What translation strategies and translation techniques were used by the translators in the face of Oulipian characteristics in the peritexts and how these contribute to the visibility of the translator? What roles do the paratext translations assign to target culture readers?

The peritexts of the translations will be analysed based on Genette's classification of paratexts. The article will first furnish background information about La Disparition and the Oulipo group in order to be able to link the Oulipian constraints with the source and target texts, then concentrate on the concept of paratexts in Translation Studies, and moves on to peritextual analysis. Finally, the article presents and comments on the main findings from the analysis.

\section{La Disparition and constrained writing}

George Perec, the author of Les Revenantes in which the only used vowel is "e", is also the author of $L a$ Disparition, a 305-page novel in which he never used "e". But how did the idea of writing such a novel

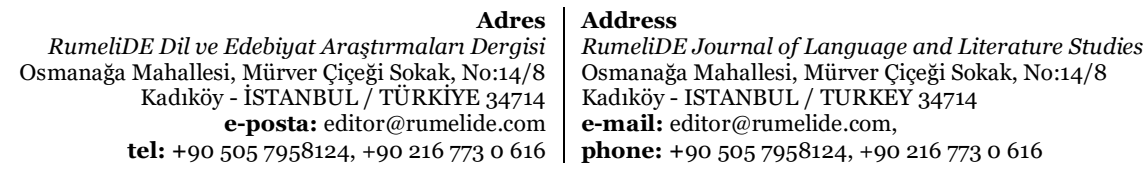


occur to Perec? The answer is simple: Perec is a member of Oulipo. ${ }^{2}$ Oulipo is a French acronym which stands for "Ouvroir de Littérature Potentielle" which may be translated into English as "Workshop of Potential Literature". It is a research group that wants to present new ideas in new forms (Oulipo, 1973). In order to achieve this aim, Oulipians practice a technique called constrained writing. Constrained writing, in general, "designates a form of literary production in which the writer submits his or her text to specific formal (and to a lesser extent also thematic) constraints" (De Geest \& Goris, 2010, p. 82). Queneau, one of the group's presidents, while trying to define an Oulipian writer, also defines constraint in the Oulipian sense: Rats that build a labyrinth from which they will try to escape. This labyrinth consists of words, sounds, sentences, paragraphs, sections, books, prose and, poetry (Oulipo, 2002). It can be said that the labyrinth that he refers to is the constraints and, the fact that they try to free themselves from something that they themselves have created shows the desire of creativity and the voluntariness of the constraint. Constraints may be literal or mathematical since Oulipians love playing with language by combining literary works with mathematics in order to reach some potentiality of meaning. For Oulipians, every literary text has its own constraints, constraints of vocabulary, grammar, etc. What they want to do is to create or fix the constraints systematically and scientifically (Oulipo, 1973).

La Disparition is a very good example of constrained writing. Throughout the book, Perec applies a constraint called lipogram which can be explained as omitting one or more letters in a text (Collombat, 2007). It may be asked why Perec avoided the letter " $\mathrm{e}$ " in preference of all the other letters. The question has 2 answers: "e" is the most frequently used vowel in French. Thus, writing without the most common letter is a challenge for an author. It is also a way to stimulate creation, an aim supported by Oulipo. Writing under this constraint would enable Perec to discover other ways of expression and also push him to force literary boundaries. The second answer to the above-mentioned question is a biographical one. Perec's family died during WW II. He tried to emphasize this loss by omitting the letter "e" which has the same pronunciation with "eux", meaning "them" in French. In other words, in his novel, he creates his world without e/ them (his family), and he is in search of his lost family. Stone (2000, p. 38) summarizes it as follows: "At the heart of Perec's work lies the experience of loss, and the need to find ways of articulating that loss not by giving explicit voice to it, but by drawing attention to something missing."

Lipogram in "e" should not be considered solely as a lexical constraint. Perec succeeded in making the lipogram not only the principle of writing but also the subject of the narration: all the characters and the plot of the study turn obstinately around a single theme, which is precisely the disappearance of a letter (which obviously cannot be named, but only suggested). His success was so strong that a theoretical explication has been formulated for Oulipian texts: every text written in a constraint must refer to this constraint (Oulipo, 1988).

\section{Oulipo and translation}

For Oulipians, translation is a central concept through which new forms of writings are created. Nevertheless, the term translation in this context is rather different than interlingual translation. Oulipian translation is a process of replacing one utterance with another by making a substitution which is essentially lexical and which affects the other components as little as possible (Oulipo, 1988). In other words, translation in the Oulipian sense is above all an intralingual translation under constraint that may be extended to phonetic, semantic and discourse levels. Antonymic, homophonic, homosemantic,

2 Use of present tense is not arbitrary. According to Oulipo, despite his death, Perec is still the member of the group.

Adres $\mid$ Address

RumeliDE Dil ve Edebiyat Araştırmaları Dergisi $\quad$ RumeliDE Journal of Language and Literature Studies

Osmanağa Mahallesi, Mürver Çiçeği Sokak, No:14/8 Osmanağa Mahallesi, Mürver Çiçeği Sokak, No:14/8

Kadıköy - İSTANBUL / TÜRKIYE 34714 Kadıköy - ISTANBUL / TURKEY 34714

e-posta: editor@rumelide.com $\quad$ e-mail: editor@rumelide.com,

tel: +90 $5057958124,+90216773$ o 616 phone: +90 505 7958124, +90 2167730616 
lipogrammatic translation, $\mathrm{S}+7$, and definitional literature are the best-known constrained writingsOulipian translations. La Disparition is also an example of Oulipian translation since it is Perec's selftranslation of Un homme qui dort using the lipogram constraint (Ruiz, 2016).

When it comes to rendering an Oulipian text into another language, that is to say, translating as it is commonly known- as interlingual translation; the translators' job becomes more difficult and creative. Clarke (2016) states that when in front of an Oulipian text, the translator should determine the visibility of constraint at the pre-translation phase and recreate the target text constraint in a similar way. Translation of constraints is more or less difficult depending on the target language's possibility of offering the tools necessary to reproduce the constraints and on the strategy adopted by the translator. Salceda and Bloomfield (2016) offer a scale to determine the degree of re-creation in which translator strategies are ranged from the translation of signified only to the reinvention of constraint.

\section{Paratranslation}

Genette (1997) excludes translation along with illustrations and serial publications from his classification, but he emphasises their paratextual relevance. Contrary to Genette and from the Translation Studies perspective, Tahir-Gürçağlar (2002), defends that considering translation as a paratext reduces the translation to a derivative activity and does not comply with the view that it is the target culture that initiates the translation. She also asserts that paratexts "can offer valuable insight into the production and reception of translated texts..." (Tahir- Gürçağlar, 2002, p. 44). Trying to expand the work of Genette, researchers working on the relationship between translation and paratext at Vigo University coined the term paratranslation in this field. Defined as an activity that analyses "the space and time of all writing that surrounds, wraps, extends, introduces and presents the actual translation", the paratranslation informs about the activities "present at the threshold of the translation, as well as about what they represent and teach in terms of the translator's subjectivity and the nature of the translated product" (Yuste-Frias, 2010, pp. 291-292, 2012, p. 118). Derived from paratranslation, the term peritranslation will be used throughout this article to express the translation of peritextual elements.

In other research carried out on paratext from the Translation Studies point of view, paratexts are seen as vital keys in examining the function of translations (Kung, 2013), as promoting elements of an author (Spittael, 2014; Vuaille-Barcan, 2011), or as instruments of cultural translation which condition the reception of the text (Watts, 2007). Paratextual elements also help to construct the meaning (Armstrong, 2007; Sapiro, 2008) and structure the reading (Alvstad, 2012). Meneghello's (2016) thesis whose focus is on Calvino's translation of Queneau's Les fleurs bleus in Italian examines systematically paratextual elements from the Translation Studies perspective.

\section{Peritranslation analysis}

In what follows, the author of the article shall first describe the peritextual element in question in both translations [Kayboluş (2006); A-void (2008)] and then tries to link these peritranslation solutions with Oulipian constraints as well as with the other peritranslation solutions in the same book. In cases where discrepancies arise, the author will try to determine the reason and question the translator's decisions. Peritranslation analysis of the title, the front cover, the table of contents and translation diaries is undertaken.

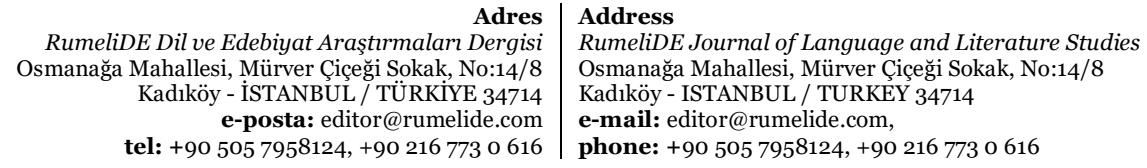




\section{The title and the front cover design}

On the front cover of TT, are written in order, from top to bottom; the title of the book, the name and surname of the author, an illustration, the name and surname of the translator, the logo of the publishing house, and the number of printings. The Turkish book subject to this study was published by Ayrintı Publishing House in (2006). (see Figure 1)

\section{Figure 1}

TT \& ET cover
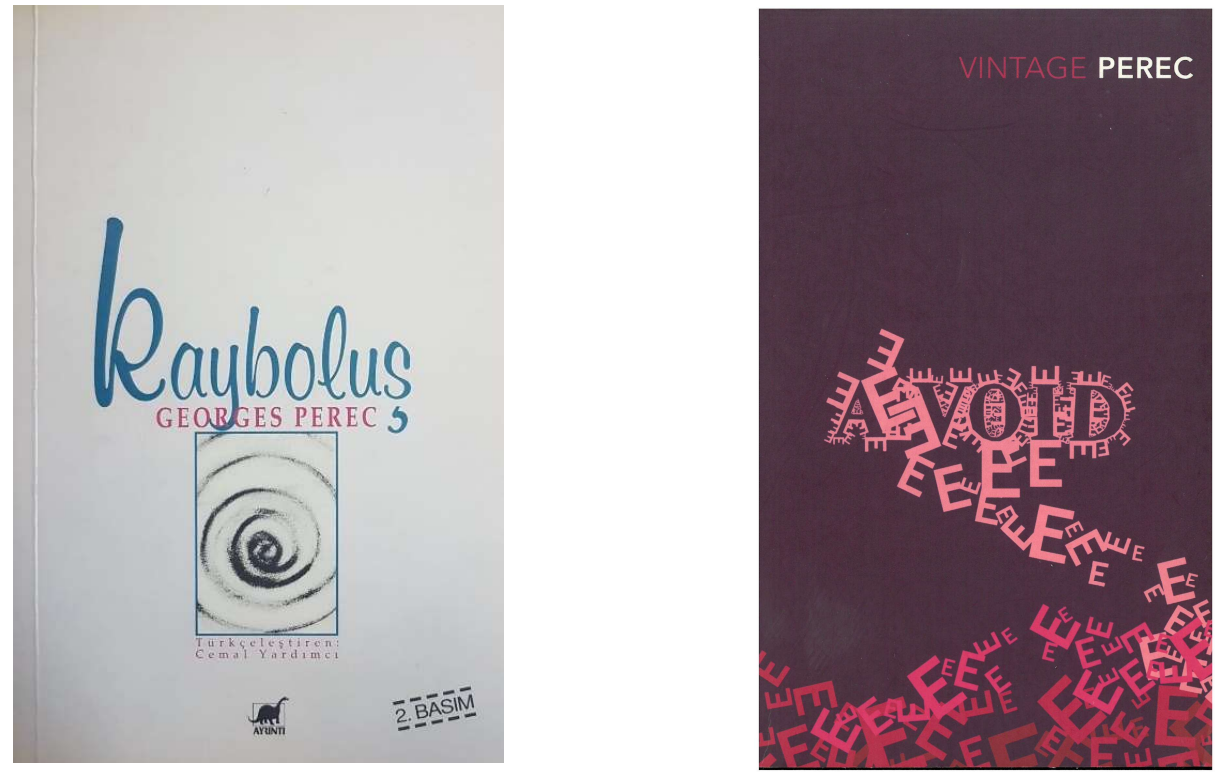

On the front cover of the English target text (ET henceforth), three elements can be distinguished: the name of the publishing house and the surname of the author in the top right corner and the title in the centre. ET was published by Vintage U.K Random House in 2008 as a part of its Classics Collection. (see Figure 1)

TT title is "kayboluş", meaning disappearance in English and does not contain the letter "e". The title is in handwritten form and does not start with a capital letter. Obviously, this style was not chosen at random. For a keen reader, it is possible to distinguish an " $\mathrm{e}$ " included in the design of the ' $\mathrm{k}$ ' as seen in Figure 1. This style not only gives a clue about the constraint in the novel, but also enhances the theme of disappearance. There is also another allusion to the absence of "e" on the cover: the illustration. The illustration is in a rectangle $5 \times 3.5 \mathrm{~cm}$ in dimensions and shows a vortex in the middle of which a reversed " $\mathrm{e}$ " can be distinguished. Here again, it is possible to interpret that the vortex has thrown away the "e". Besides, a vortex is a familiar figure for Oulipians since it is used in 'sestina', another Oulipian technique in a fixed verse form. It should be noted that all these allusions are implicit, that is to say, they may not be noticed at first glance.

ET title is "A VOID". As can be seen, like TT there is no "e" in the title but unlike TT, the title is written in capital letters. It is placed in the centre of the cover and is the same colour as the background. What makes it possible for the reader to discern the title is the numerous "e"s that are printed in a different

RumeliDE Dil ve Edebiyat Araştırmaları Dergisi Osmanağa Mahallesi, Mürver Çiçeği Sokak, No:14/8 Kadıköy - ÍSTANBUL / TÜRKIYE 34714 e-posta: editor@rumelide.com tel: +90 $5057958124,+902167730616$
Address

RumeliDE Journal of Language and Literature Studies

Osmanağa Mahallesi, Mürver Çiçeği Sokak, No:14/8

Kadıköy - ISTANBUL / TURKEY 34714

e-mail: editor@rumelide.com,

phone: +90 $5057958124,+902167730616$ 
colour (pink) and placed just behind the title, falling down to the bottom through the space between "A" and "VOID". The style explains what is to be avoided: the "E's" are gone. The allusion to the theme is made explicit by the cover design.

TT has an off-white/greyish background. The colour white has importance in the story because as described by Chauvin (2012), it has been linked to the idea of disappearance: in Voyelles, Rimbaud's poem that has been rewritten in constraint in the French source text (FT henceforth), Perec attributes colours to vowels and writes "blank" in the place of "e". Furthermore, the front cover of FT is white. In this sense, TT's front cover is in conformity with the idea of disappearance and "e" is linked with white in the translated poem. Moreover, both in FT and TT there is a missing chapter and, the page on which this chapter should begin was left blank so that, only the whiteness of the paper is seen.

ET has a purple cover on which the title is also written in purple. It is the pink background of the E's that enables us to read it. The colour white is not used anywhere in this design. Yet, this is not sufficient to suggest that the concept of disappearance is not represented on the cover because another colour might be representing the void. It can be considered that disappearance is symbolized by pink because of the pink "E's" on the cover. To support this, when using the poem of Rimbaud and blank page for the omitted chapter as a comparison, the blank page would need to be pink and "e" would be linked with pink in the poem. However, this is not the case. Instead, "e" is linked with white in Rimbaud's poem. Thus, ET fails to link the disappearance idea with white.

On the cover of the TT, the names of the author and the translator are written and "e"s are used. These parts are written in red and therefore it forms contrast with the cover's colours -grey and blue. On FT cover also the name of the author as wells as the name of the collection containing "e"s are written in red on white background. The use of the colour red can be explained as follows: in general, the places written in red are either wrong, need to be corrected or discarded, or are the places where attention is desired. Therefore, it can be said that these obligatory parts contributed to the omission of the "e". On the cover of the ET only the surname of the author is present with two "e"s but it fits to the overall cover design making explicit allusions.

In summary, in both translations of the title the lipogram of "e" was applied and while TT makes implicit allusions to the idea of disappearance and succeeds in linking it with white, ET makes explicit allusions, but fails to link it to white.

\section{The table of contents}

The table of contents (ToCs henceforth) shows a lot about the novel, constrained writing, and translation strategies. Therefore, its structure and location are significant in these target texts. ToCs of TT and ET shows that they have sections divided into chapters. Every section and every chapter is numbered. Chapters are numbered consecutively from the first to the last. However, ToCs of TT is so markedly different from ToCs of ET that one may wonder if it refers to the same source text: First of all, it can be seen in ToCs that TT has 29 chapters while ET has 26 . Secondly, TT omits the $6^{\text {th }}$ chapter while ET omits the $5^{\text {th }}$. And thirdly, TT consists of 9 sections but ET has 6 . The question of why the translators made such different end-products must be asked.

Bearing in mind that La Disparition is an Oulipian novel, a link should be made between the numbers and the language. The author of the article has already said that Perec avoided the letter "e" and she

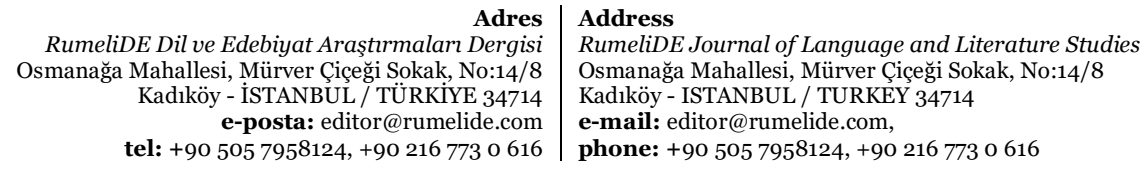


deduced in the title analysis that the lipogram of the same vowel was applied in the two translations. Therefore, it would be reasonable to suggest a mathematical reason which would take into account the omitted letter and the above-mentioned numbers: "e" is the $5^{\text {th }}$ letter of the English alphabet and the $6^{\text {th }}$ in Turkish. This explains the different positioning of the blank page/chapter in both versions. It is also a clue that guides us to discover the connection between 29 and 26. The English alphabet consists of 26 letters while Turkish consists of 29 letters and hence the book chapters are organized according to the number of letters in the given language.

ToCs of TT makes it clear that Yardımcı used the Oulipian link for Turkish which led him to change 26 to 29 which corresponds to a letter of the alphabet. Nevertheless, it is not simply a matter of replacing one number with another since each number has its own chapter/ story that contributes to the plot of the narrative. Therefore, increasing the number of chapters to 29 in TT means having 29 stories, in other words adding new stories to the novel. Facing this challenge, Yardımci inserted some chapters into the story line. In ET, ToCs uncovers the missing section by leaving a blank line in the table's $5^{\text {th }}$ line. Since the English and French languages share a common alphabet, only reading ToCs is not sufficient to determine whether or not Adair adapted the Oulipian link in ET. Further analysis of the main text is needed.

As for the sections, the English/French alphabet has 6 vowels; therefore, ET has 6 sections. The Turkish alphabet has 8 vowels, but TT has 9 sections. According to Ekici, a Turkish translator who rendered another Oulipian work Exercises of Style into Turkish, Yardımcı translated the numbers taking into consideration Oulipian features of the novel but he did not explain why he decided upon 9 sections. Yet, in order to obtain 6 sections at the end, but to express 8 vowels, Yardımcr combined two vowels into the $3^{\text {rd }}$ and $5^{\text {th }}$ sections.

Having analyzed the structure of ToCs, the article will now move on to its place in the book. In TT, ToCs is located at the end of the novel. This is unusual for Turkish readers because in Turkish novels, ToCs is rarely used, but if it is, it is situated before the main text. This placement can be justified as follows: Both the cover and Yardımcı's diaries make implicit allusions to the lipogrammatic feature of the text. However, ToCs, due to its visual character, shows at once the missing chapter and the chapters which were added by the translator. Therefore, ToCs acquires by nature a revealing function that does not comply with the implicitness of the other peritextual elements. And so, the reason that it is located at the end, may be to show what is missing to the puzzled reader who is unable to identify the link in the first place. Hence, ToCs may be considered as the solution to the ongoing game throughout the book. It is the final place which compiles what has been described both in the thematic and formal perspective. The location of ToCs is different in ET; it is placed at the front part of the book and gives an explicit indication to the reader about the avoided letter. When considered with the other peritextual elements, it conforms with the explicitness derived in the analysis of ET's cover design and title.

In summary, the structure of ToCs clearly shows the adaptation of the Oulipian link in TT while its location contributes to the implicitness of other peritextual elements. In ET and FT, ToCs has the same structure, but its location is different due to the explicitness of ET.

\section{Added chapters -translation diaries}

As Kellman (2010, p. 14) points out "translators memoirs and personal testaments also serve as paratexts". In ET, from the Oulipian perspective, there is no need to insert additional chapters due to

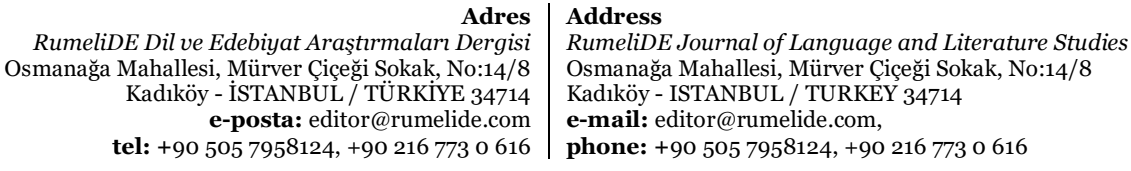


the common alphabet. In TT on the other hand, Yardımcı intervened in the $5^{\text {th }}, 10^{\text {th }}, 17^{\text {th }}$ and $24^{\text {th }}$ chapters where he states with subtlety the task he had to undertake. In these chapters that do not incidentally alter the story's plot, he expresses in an implicit way what he is trying to do and why he must do so in this manner: "If I had the option not to, I would not reveal myself and intervene in the story. [...] I leave to the readers understanding what kind of obligation I have been restricted to."3 (Perec, 2006, p. 56)

In the $24^{\text {th }}$ chapter Yardımcı intimates the difficulty of writing and translating under constraint: "[Perec] was free to tell what he could and be quiet about what he could not. But for my part, my duty was sometimes to express what I could not." (228) Of course, lipogram of "e" is applied in all the diaries.

In summary, the quotations above show that Yardımcı used the inserted chapters mostly as translation diaries to intimate the constraint of "e" and justify his translation solutions. Implicit allusion to the lipogram in these diaries is in accordance with the implicitness of the cover and the title.

\section{Functions of peritexts and role of readers}

Genette (1997) grades paratexts by their illocutionary force and illustrates several examples among which two that best suits the target texts can be depicted: First, he states that some may acquire performative function that is, the ability to perform what they describe, and second, others may have a command form, i.e., "this book must be read as..." The analysis has shown that the idea of disappearance is expressed through implicit allusions in TT. The puzzle (i.e., what is missing, what the author is writing about) is solved only at the end of the novel. The whole novel pursues the lost "e" without using it. Therefore, it can be said that peritextual elements of TT have a performative function since TT peritext performs what the book describes, in other words, the textual organization reflects what the theme is about. In ET, on the other hand, allusions to the void are explicit beginning from the front cover. What is to be avoided is implied on the cover and in ToCs just before beginning the act of reading, it is as if suggesting: this book should be read by testing the constraint. Thus, it is possible to state that peritextual elements of ET have a command form, an imperative function 4 .

The allusions also determine the position of the reader. Peritextual elements in TT lead the reader to solve a puzzle/game; the reader tries to find it out during the process of reading. In this sense, s/he is passive. In ET, peritextual elements transform the target audience to an active reader who, knowing the rule beforehand, tests the constraint and shows active participation during reading (Akdağ, 2011).

\section{Translators' strategy}

La Disparition has been translated into many languages and the translations are also lipograms. Translators have tried different ways to challenge Perec's work in their own language. Adair omitted the letter "e" because of its frequent use in English. Yardımcı also excluded the same vowel, but in Turkish "e" has a lower frequency than "a" (9.01\% vs.11.68\%) (Karahan, 2014). Thus, why did not he prefer a vowel of higher frequency? Although at first, Yardımcı's choice may seem surprising, it is not ungrounded. Ekici states in his blog that if the novel were a lipogram in "a", due to the vowel harmony in the Turkish linguistic system, the text would make the reader laugh. Such a text would require that the novel be rewritten entirely, and in this case, it would not be possible to talk about a translation. When

3 Unless otherwise stated, translations are mine. In their Turkish version, no "e" was used.

4 Genette does not use the term "imperative function". This term is a suggestion.

RumeliDE Dil ve Edebiyat Araştırmaları Dergisi $\quad$ RumeliDE Journal of Language and Literature Studies

Osmanağa Mahallesi, Mürver Cicceği Sokak, No:14/8 Osmanağa Mahallesi, Mürver Çiçĕ̌i Sokak, No:14/8

Kadıköy - İSTANBUL / TÜRKIYE 34714 Kadıköy - ISTANBUL / TURKEY 34714

e-posta: editor@rumelide.com $\quad$ e-mail: editor@rumelide.com,

tel: +90 505 7958124, +90 216773 o 616 phone: +90 505 7958124, +90 216773 o 616 
other translations of La Disparition are examined, it can be seen that like Yardımcı, translators omitted the most convenient vowel for their respective language: The Russian translator decided to omit the most frequently used vowel 'o', but assumed that the challenge would be too easy, and hence tried to eliminate both "a" and "e". However, this choice made it impossible to compose a text and finally, he decided only on 'o'. Also, the Croatian translator stated that Croatian resembles Spanish more than French thus, she hesitated between "a" and "e" (Spanish version is a lipogram in "a") and because the name 'Perec' contains two "e"s and the letter carries with it so many connotations, she decided on "e" (Bloomfield, 2012).

Yardımcl's translation strategy can also be mapped through translation diaries. In the $5^{\text {th }}$ chapter he explains his desire to create the same effect on readers:

"When I had to intervene and take the floor, I thought about presenting a few clues outside the context of the narrative, making some explanations that would not contribute to the novel, but would increase the readers' possible taste of the reading of this adaptation. I froze as soon as I started to work in this direction. Would not it be disrespectful to Perec and the Turkish readers to provide an explanation that Perec did not himself provide to the French readers?" (italics mine5)(Perec, 2006, p. 56)

He also reveals his pre-translation decisions there:

"I did not try to make a copy of the painting that he [Perec] painted with the local paints and brushstrokes that I could find. I tried to put the mirror of our tongue against his painting (even if it was a little indented, jagged).” (Perec, 2006, p. 228)

He rejects that TT is an adaptation "I tried to stay so faithful to the source that I do not consider this translation as an adaptation." and claims that his translation is faithful to the source text: "I have dealt with the narration word-for-word. I tried to translate mot-à-mot” (Perec, 2006, p. 228).

A quick look to the epitext shows that Yardımcı was heavily criticized by some scholars and well -known authors for having added chapters and having called himself as "half-author" in the book. For example, Tahsin Yücel stated: "I have not seen the book but adding is a completely unnecessary approach. Because then what we do is no longer a translation" (Atmaca, 2006). Ferit Edgü asked how the publishing house could share the nonsense of the translator. However, Yardımcı has a justifiable answer to all these criticisms. He had to use the word "half-author" because in Turkish all the synonyms of translator contain "e" and he had to intervene because of the constraint application.

ET peritranslation strategy remains more hidden due to the English- French alphabet affinity. However, Adair pursues the explicitness in his peritranslation decisions: Apart from the cover design that shows falling E's, he brought ToCs to the front to emphasise what was missing. Moreover, he renders the reader more active by providing the opportunity to test the constraint.

When these translators' decisions were analysed, it could be seen that they acted differently. In order to meet the matricial considerations, Yardımcı adopted a different segmentation in Turkish and reorganized peritextual material accordingly in order to assure the fullness of the Oulipian features. Undoubtedly, this reorganization can't be achieved without the help of translation techniques. First of all, he used addition: He intervened into the story line by inserting chapters and section numbers to meet the constraint requirements. Besides this, he made use of the omission technique by not inserting

Yardımcı calls Perec as "bearded master" since in Turkish "sakallı üstat" does not contain "e".

Adres Address

RumeliDE Dil ve Edebiyat Araştrrmalar Dergisi $\quad$ RumeliDE Journal of Language and Literature Studies

Osmanağa Mahallesi, Mürver Çiçeği Sokak, No:14/8 $\quad$ Osmanağa Mahallesi, Mürver Çiçeği Sokak, No:14/8

Kadıköy - İSTANBUL / TÜRKIYE 34714 Kadıköy - ISTANBUL / TURKEY 34714

e-posta: editor@rumelide.com $\quad$ e-mail: editor@rumelide.com,

tel: +90 $5057958124,+90216773$ o 616 phone: +90 505 7958124, +90 2167730616 
the $6^{\text {th }}$ chapter due to the constraint. Likewise, Adair left the $5^{\text {th }}$ chapter blank by using the same technique for the same reason. Also, Adair relocated ToCs by placing it at the front.

\section{Constraint and translator visibility}

Based on Bénabou, Clarke (2016) cites 3 types of constraint visibility as forced revelation, external revelation, and internal revelation. In forced revelation, the reader should know the constraint beforehand in order to be able to understand the text whereas in the external revelation the reader is unaware of the presence of the constraint unless s/he is told so. In La Disparition, Perec opted for internal revelation, which is the text itself gives clues to the reader to figure out the constraint.

In internal revelation, the translator "must be certain to have picked up on the hints left by the author and to have left the same or similar clues in the text for the target audience." (Clarke, 2016, p. 885) The afore-mentioned characteristics of TT are enough to determine that constraint visibility is internal in TT since the peritext is part of the constraint both in linguistic and thematic terms and Yardımcı has left clues in peritexts for the target audience (organisation of ToCs, translation diary, image on the front cover). In fact, while giving hints about his translation strategy in the $5^{\text {th }}$ chapter, he also made sure to create the same effect for Turkish readers by not explaining directly the obligation pushing him to insert these diaries. For ET, things are less consistent. Although the constraint visibility seems to be internal in the majority of the peritext, there are parts that do not fit with the constraint (the colour white in the poem vs. Pink E's on the cover and the blank pages) and that may puzzle the target reader.

These different decisions led to differences in target texts' recreation degree. In order to determine the translations recreation degree, Salceda and Bloomfield (2016) offer a 4-grade scale in which degree o refers to translation of signified only without taking account the constraint; degree 1 , translation of signified and prioritisation of constraint; degree 2, very faithful translation of constraint at the expense of semantics; degree 3 , translation of semantics and the constraint; and finally degree 4 , reinvention of the constraint and / or additions of semantic layers by exploiting the possibilities of the target language. Taking into consideration TT peritranslation characteristics, it can be said that degree 4 is reached in TT since Yardımcı reused the constraint following the language possibilities: He added translation diaries and omitted a different chapter while changing section numbering. Moreover, TT peritext allusions to the main text (white colour on the front cover and white colour in the poem, illustration) were found consistent. In ET, on the other hand, the allusion to the idea of disappearance on the front cover design and in the main text is not consistent with regards to colour choice. Thus, it is possible to say that degree 2 was achieved.

The translator is visible in TT. The fact that his full name is written on TT's front cover, contributes to his visibility. Furthermore, the added chapters start with this statement "Here, C. Yardımc1, [...] intervenes as a result of an obligation." in which his name figures. Adair is not visible on ET's peritext.

\section{Conclusion}

Writing under a constraint is a challenge for any author. Translating what is written under constraint into another language and applying the same constraint is even more of a challenge for a translator. Translators try to surmount this painstaking task, especially when faced with Oulipian texts, since these are formed under some linguistic, thematic or mathematical constraints and the constraints may be found not only in the main text but also in any part of the work, i.e., peritext, epitext. Taking as a subject

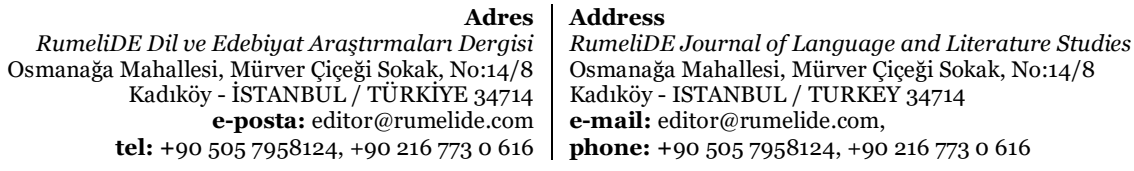


of study the Turkish and English translations of Perec's famous novel La Disparition, this study contributes to paratranslation research by analysing both peritextual elements and Oulipian constraints from the Translation Studies point of view. Most salient peritextual elements of the book such as the front cover, the title, ToCs, and translation diaries were analysed based on Genette's classification of paratexts. Analysis showed that the front cover of TT makes implicit allusions to the main theme of the book, i.e., the disappearance, and this peritextual element is in accordance with the main narration about linking the white colour with the idea of disappearance. The place of ToCs also contributes to the implicitness of the TT. Conversely, ET cover and the place of ET ToCs make explicit allusions to the idea of disappearance but, the cover does not link the white colour with the idea of disappearance. As for the translators, Yardımc is visible on TT cover and TT ToCs. Implicit allusion to the lipogram in the diaries is in accordance with the implicitness of the cover and the title. Adair is not present on ET peritext. Yardımcı recreated the constraint by adding some chapters and by exploiting the possibilities of the target language. Adair, on the other hand, translated the constraint faithfully but the peritext-main text connection was not always consistent. All these translation decisions led the translation acquire a performative function in TT and imperative function in ET while they made the reader active in ET, passive in TT.

This paper focused on how different peritranslations of the same book could alter its reception in target cultures and showed that differences in peritranslations altered the role of readers, changed the function of peritextual elements in target texts, strengthened or weakened the visibility of the constraint as well as the visibility of the translator and affected the recreation degree of the main text. The present study brought to light the peritranslation of a specific book, the results of which may be enlarged by taking into account other Oulipian paratexts in different language pairs. For the Turkish and English pair, it is clear that the translators created differences with their products. Adair was awarded the Scott Moncrieff Translation Prize for his work. Yardımcı's translation became a subject of debate among critics and opened a way to discuss the nature of translation along with the task of the translator.

\section{References}

Akdağ, A. I. (2011). Oulipo metinlerinin Türkçeye çevirisinin olanaklari: Yazın dizgesinde boşluğu doldurma araci olarak deyiş kaydirmalari. İÜ Çeviribilim Dergisi, 2(3), 81-116.

Alvstad, C. (2012). The strategic moves of paratexts: World literature through Swedish eyes. Translation Studies, 5(1), 78-94. https://doi.org/10.1080/14781700.2012.628817

Armstrong, G. (2007). Paratexts and Their Functions in Seventeenth-Century English" Decamerons. The Modern Language Review, 40-57. https://doi.org/10.2307/20467151

Atmaca, E. (2006). Çevirmen yarı yazar mı? Radikal. Retrieved from http://www.radikal.com.tr/kultur/cevirmen-yari-yazar-mi-772746/

Bloomfield, C. (2012). Traduire 'La Disparition' de Georges Perec. Retrieved from https://www.academia.edu/2645162/Traduire_La_Disparition_de_Georges_Perec

Chauvin, A. (2012). La Saga du Scriptural: Occultations, Duplications. Semen. Retrieved from http://semen.revues.org/5613

Clarke, C. (2016). The Impact of Constraint Visibility on the Translation of Constraint-based Writing. MLN, 131(4), 877-891. https://doi.org/10.1353/mln.2016.0063

Collombat, I. (2007). L’Oulipo du Traducteur. Semen. Retrieved from http://semen.revues.org/2143

De Geest, D., \& Goris, A. (2010). Constrained Writing, Creative Writing: The Case of Handbooks for Writing Romances. Poetics Today, 31(1), 81-106. https://doi.org/10.1215/03335372-2009-015

Genette, G. (1997). Paratexts: Thresholds of interpretation. Cambridge: Cambridge University.

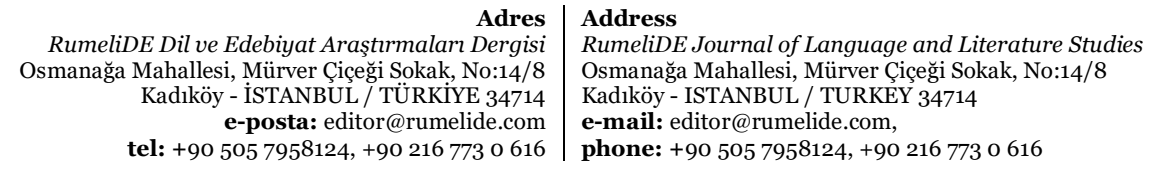


Karahan, A. (2014). Kripto sistemlerde Türk Alfabesi Kullanımı: Şifreleme ve Kriptanaliz. Unpublished Poster Presented at Ted Ankara Koleji. Retrieved from http://tedprints.tedankara.k12.tr/422/

Kellman, S. G. (2010). Alien autographs: how translators make their marks. Neohelicon, 37(1), 7-19. https://doi.org/10.1007/s11059-010-0041-1

Kung, S. (2013). Paratext, an Alternative in Boundary Crossing: A Complementary Approach to Translation Analysis. In V. Pellat (Ed.), Text, Extratext, Metatext and Paratext in Translation (pp. 49-68). Cambridge Scholars Publishing.

Meneghello, H. (2016). Italo Calvıno e o intrincado jogo da tradução literária: reinventando Queneau. University of Santa Catarina.

Oulipo. (1973). La Littérature Potentielle: Créations Re-créations Récréation. Paris: Gallimard.

Oulipo. (1988). Atlas de Littérature Potentielle. Paris: Gallimard.

Oulipo. (2002). Abrégé de Littérature Potentielle. Paris: Mille et une nuit.

Perec, G. (1969). La Disparition. Paris: Denoel.

Perec, G. (2006). Kayboluş. İstanbul: Ayrıntı.

Perec, G. (2008). A Void. London: Village.

Ruiz, P. M. (2016). Ways to Start Looking at Potential Translation. MLN, 131(4), 919-931. https://doi.org/10.1353/mln.2016.0066

Salceda, H., \& Bloomfield, C. (2016). La contrainte et les langues (portugais, italien, français, espagnol, anglais). MLN, 131(4), 964-984. https://doi.org/10.1353/mln.2016.0070

Sapiro, G. (2008). Translation and the field of publishing. Translation Studies, 1(2), 154-166. https://doi.org/10.1080/14781700802113473

Spittael, T. (2014). The Peritextual Framework of Jean-Jacques Rousseau's First Discourse in Eighteenth-Century English Translations (1751-1779). ANQ: A Quarterly Journal of Short Articles, Notes and Reviews, 27(2), 69-75. https://doi.org/10.1080/0895769X.2014.913945

Stone, D. (2000). Grasping what isn't shown: Georges Perec, Ellis Island and Jewishness. Jewish Quarterly, 47(2), 37-40.

Tahir- Gürçağlar, Ş. (2002). What Texts don't Tell The use of Paratexts in Translation Research. In T. Hermans (Ed.), Crosscultural Transgressions: Research Models in Translation Studies II: Historical and Ideological Issues (pp. 44-60). Manchester: St.Jerome.

Vuaille-Barcan, M. (2011). Douglas Kennedy or an American in Paris: Paratextual Strategies an 'Acclimatization' of the Translated Text. In A. Vuaille-Barcan, ML; Rolls (Ed.), Masking Strategies:Unwrapping the French Paratext (pp. 69-84). Peter Lang.

Watts, R. (2007). Translating Culture: Reading the Paratexts to Aimé Césaire's Cahier d'un retour au pays natal. TTR: Traduction, Terminologie, Rédaction, 13(2), 29-45. https://doi.org/10.7202/037410ar

Yuste-Frias, J. (2010). Au seuil de la traduction: la paratraduction. In Event or Incident. Événement ou Incident. On the Role of Translation in the Dynamics of Cultural Exchange. Du rôle des traductions dans les processus d'échanges culturels (pp. 287-316).

Yuste-Frias, J. (2012). Paratextual Elements in Translation: Paratranslating Titles in Children's Literature. In P. O. \& S. R.-E. Gil-Bajardi, Anna (Ed.), Translation Peripheries. Paratextual Elements in Translation.

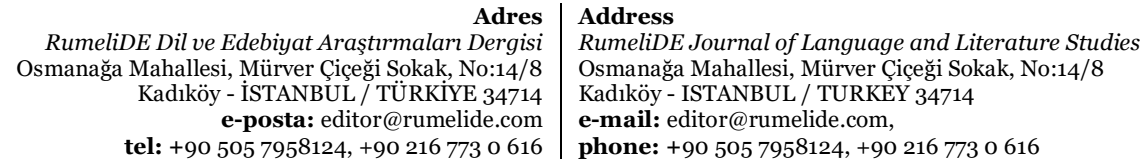

tel: +90 $5057958124,+902167730616$ 